\title{
Hannah Arendt
}

Andens liv. Oversat af Joachim Wrang, introduktion ved Hans Jørgen Schanz. Forlag KLIM 2019. 530 s.

Ved den tysk-amerikanske tænker, Hannah Arendts død i 1975 fandt man et stykke papir med titlen Judging, at dømme, i hendes skrivemaskine. Efter nogle dage forinden at have færdigredigeret at ville var det nu tid til at undersøge dømmekraften. Sammen med en undersøgelse af at tonke var at ville og at dømme tiltænkt at skulle udgøre de tre dele i en samlet beskrivelse af Andens liv.

Værkets ydre tilblivelseshistorie er Arendts to forelæsninger afhold i forårene 1973 (at tanke) og 1974 (at ville) som inviteret gæst til at afholde The Gifford Lectures ved University of Aberdeen. Planen var, at Arendt skulle afholde en sidste forelæsning i foråret 1976 om at domme. Med hendes pludselig død blev denne forelæsning ikke til noget, hvorfor det er Arendts litterære eksekutor Mary McCarthy, som efter Arendt død har forestået den endelig redigering og udgivelse.

Åndens liv er et så komplekst og teologisk-filosofisk historietungt værk, at ethvert forsøg på at gengive Arendts læsninger af disse fags historier som argument for sine analyser af de tre åndelige aktiviteter i sig selv kræver en selvstændig bog, og derfor - indlysende - ikke skal forsøges her.

Teologisk mest interessant er værkets anden del, at ville. Her undersøger Arendt dels viljen, dels handlingen som kærlighed til en ny begyndelse. Afsættet er "Augustin, den første viljesfilosof" og dennes nytolkning af antikkens forståelse af frihed fra jeg kan til jeg vil. Augustins forskydning i frihedsforståelsen fra evne til intention sker i dialog med Paulus' Romerbrev, hvor Augustin omtolker Paulus' ydre handlingssplittelse til en indre viljessplittelse: "[i] forbindelse med hver eneste viljesakt er der et jeg-vil og et jeg-nærer-modvilje” (320). Augustin omskriver Romerbrevets berømte kapitel 7 til, at det både var "mig, der ville, og mig, der ikke ville. Jeg var mig selv; men hverken i at ville eller ikke at ville var jeg helt mig selv. Derfor kæmpede jeg med mig selv og blev splittet" (324).

Den synd, der bor i mig, er ikke et misforhold mellem to love, men en sønderret og adspredt vilje, som kun kærlighed kan forløse mig fra. I kærlighed forenes de mange viljer til én og tynger den indre åndelige aktivitet at ville til i handlingen at forene sig med den ydre verden. Dermed ophører viljen med at ville.

At kærlighed forener viser Arendt med venskabet som eksempel. To mennesker er venner, og danner i kraft af venskabet en enhed med hinanden, men samtidig vedbliver de også at være to uafhængige, men ens substanser. Det sidste er af afgørende betydning, for da kun det ensartede kan forenes, er dette for Arendt et vidnesbyrd om, at splittelse ikke skyldes "menneskets dobbelte væsen, halvt kødelige og halvt åndelige” (323), men er at finde i viljen selv. Derfor kan viljen og modvilje, også forenes $i$ kærlighed, dvs. bli- 
ver til: tre-i-en! Treenigheden bevidner, at "[d]er er en i mig, der er mere mig selv end mig selv" (327). Foreningen, der er er mere mig end min splittede ånd, er viljen forvandlet til et liv i kærlighed, og hvilken kærlighed er større end at kunne sige "Jeg vil, at du er - Amo: Volo ut sis" (333).

Således vender den til kærlighed transformerede vilje sig mod fremtiden i håbet om en ny og vedvarende begyndelse og ikke blot, som hos grækerne, en evig cyklisk gentagelse af fortiden. Arendts prioritering af viljen blandt åndsevnerne åbner op for en afsluttende kritik af Augustin som hængende fast i idéen om menneskene som dødelige væsener. Kritikken er også en kritik af Martin Heidegger, og hans bestemmelse af Dasein som en Seinzum-Tode. Som skabt af den skabende Gud er hvert enkelt menneske i kraft af sin fødsel skabt til en ny begyndelse. Det er menneskets fødthed og ikke dets dødeligehed, der definerer mennesket. Dets fødthed giver menneskene mulighed for med frihedens spontanitet at afbryde et igangværende hændelsesforløb og initiere en ny række i tiden. Menneskene er med andre ord hverken bundet af fortiden eller tynget af en dødsbevidsthed, men skabt til i kærlighed at handle således, at du stadig kan være til!

Med Åndens liv har en af det 20. århundredes store tænker skrevet et af de allervigtigste værker, og heldigvis foreligger dette nu i en særdeles fornem oversættelse af Joachim Wrang. Roses bør også den grundige korrektur, og Hans Jørgen Schanz' læsevenlige introduktion, der kompetent indfører nye læsere i Arendts tænkning. Nye læser af Arendt kan med stor fordel begynde her. Og lad det være sagt en gang for alle: Selvom Arendt var jøde og ikke i direkte forstand så sig selv som kristen tænkning, må Åndens liv være et sine qua non for den teologiske refleksion i dag.

Niels Mattsson Johansen

\section{Carmen Angela Cvetkovic \& Peter Gemeinhardt (red.)}

Episcopal Networks in Late Antiquity. Connections and Communication across Boundaries. Arbeiten zur Kirchengeschichte, 137. Berlin/Boston: de Gruyter. 2019. 365 s. $€ 99,95$.

Denne bog indikerer, at kristendommen i oldkirken i et vist omfang blev spredt og i høj grad formet i kraft af netværk mellem biskopper indbyrdes og mellem biskopper og folk med magt uden for kirkerne. Bogens indledning bringer en kort forskningsoversigt som baggrund for 14 case-studier, der arbejder med en bred vifte af emner, geografiske områder og tidslige afgrænsninger foruden med meget forskellige former for kilder, oftest dog breve. Studierne blev første gang fremlagt på en konference i Göttingen i 2016. Bogen har ikke en konklusion (og desværre heller ikke noget kort over de mange nævnte lokaliteter), men sluttes med grundige indekser over kildetekster med forfattere, oldkirkelige lokaliteter samt moderne forfatte- 